\title{
Becoming a mother: teenage mothers' experiences of first pregnancy
}

\author{
MS Maputle, D.Cur \\ Nursing Department, University of Limpopo (Turfloop Campus)
}

\section{Keywords:}

Teenage mothers; motherhood

\section{Correspondence address:}

Dr MS Maputle

School of Health Sciences

Nursing Department

University Of Limpopo (Turfloop Campus)

P/Bag X1106

Sovenga

0727

Tel : (015) 268-2384

Fax : (015) 268-3080

E-mail : maputlem@ul.ac.za

\section{Abstract: Curationis 29(2): 87-95}

The purpose of this study was firstly to explore and describe the experiences of teenage mothers of first pregnancy. Secondly, to develop guidelines of a support programme that is contextual and relevant to the needs of teenage mothers. The guidelines are aimed at assisting midwives in meeting the needs of teenage mothers. An exploratory, descriptive, contextual and qualitative design was used. The phenomenological approach was implemented to collect and analyze data from a purposively selected sample of fourteen (14) teenage mothers who were pregnant for the first time. The model of Guba and Lincoln (1985: 301-318) was implemented to ensure trustworthiness in this qualitative study. Five themes emerged from the analysis of the data. Guidelines and recommendations for support programme were developed.

\section{Introduction}

Pregnancy is viewed by psychologists as a time of crisis brought about by emotional, psychological and social stress which reflects the identity crisis of becoming a mother (Bribing, 1959 in Niven and Walker, 1996:45; Tarkka, Paunonen \& Laippala, 2000:184). It has the distinction of being an event that is culturally, socially and physically transformative and must be viewed in the context in which it occurs (Schneider, 2002:238). The onset of pregnancy is an important transitional period during which women experience many physiological, emotional and psychological changes in their lives (Mercer, 1986:52). For young women, pregnancy was found to mark the transition from girlhood to womanhood (Seibold, 2004:173). Many teenage mothers who were pregnant for the first time at particular clinics at the Capricorn District, Limpopo Province, were still biologically immature and still at school. During pregnancy, the expectant mother undergoes major physiological and psychological adjustments. Teenagers have less time of assimilating body changes from pubertal growth before having to inco-operate changes occurring with pregnancy.

Tarkka et al (2000: 184) were of the opinion that in the early pregnancy stage a woman might have bad feelings about her future motherhood, especially if she felt that the timing was wrong.

The symptoms of teenage pregnancy are not different from that of normal pregnancy. These include missed period, fatigue, nausea and vomiting, breast enlargement and tenderness, weight gain and increased moodiness.

Lack of information regarding these physiological changes was displayed when statements like "I didn't know that missing menstrual period is a sign of pregnancy". With increasing body size, most of these teenage mothers thought they were fit. Since they placed greater emphasis on physical appearance and trim figure, they felt clumsy, unattractive, ugly or fat and experienced difficulty in accepting their image. Inspite of experiencing these symptoms, the pregnant teenager did not tell anyone about the pregnancy; and as such, they were often not noticed by family members. (Nolte, 1998:73; Seibold, 2004:178).

Because their pregnancies were often not planned the teenage mothers felt shy and embarrassed. They therefore, wore bigger clothes to conceal the pregnancies. Bookings at the clinics were also only made when they were at an advanced stage of pregnancy, or confirmation of the pregnancy was mostly done by a general practitioner at approximately 32 - 
36 weeks. Niven and Walker (1996:42) indicated that attitudes towards pregnancy varied from society to society. In some societies, teenage pregnancy was regarded as a source of embarrassment because of its association with sexuality and was therefore kept a secret for as long as possible. This could have negative implications for health care, which may not be provided for until late in the pregnancy, or if available, may not be utilized at all. The notion was further supported by Chandria, Schiavello, Ravi (2002:121) who pointed out that poor attendance to the antenatal clinic had potential adverse effects such as low birth weight and intra-uterine growth retardation.

In this study, the researcher was of the opinion that when there was poor attendance to the antenatal clinic, teenage mothers missed the opportunity of receiving accurate information on basic physiological, psychological changes and advices on self care during pregnancy from the midwives. It is assumed that these could contribute to negative experiences. Tarkka et al (2000:186) in the study on "The importance of the midwives in the first time mother's experience of childbirth", pointed out that the first time mothers experienced pregnancy and childbirth as something more negative than positive. Women were experts of their own lives, yet there was a lack of documented literature about experiences of their first pregnancy. They further pointed out that the mothers' experiences of pregnancies deserved more attention if appropriate and sensitive care was to be provided to women in South Africa. Rice and Naksook (1998:74) were of the notion that it is only when women voices were heard in all aspect of health care delivery that we might provide better and appropriate health care services for women at childbirth.

\section{Problem statement, research questions and objectives}

Teenage mothers who are pregnant for the first time experience physical, psychological and emotional changes. The knowledge of these experiences could assist midwives in determining their needs and to develop guidelines for support programme. The study was conducted in order to answer the research question outlined below:
- What are the teenage mothers' experiences (physical, psychological, emotional and cultural) of their first pregnancies?

\section{Objectives}

The objectives of the study were to:

- $\quad$ explore and describe teenage mothers' experiences of their first pregnancies.

- $\quad$ develop guidelines for support programme that will assist midwives in meeting the needs of teenage mothers who are pregnant for the first time in the Capricorn District, Limpopo Province.

\section{Paradigmatic perspective}

The research was based on The Theory for Health Promotion in Nursing (Nursing Department RAU: 2000). This theory reflects the focus on the promotion of health of the individual, family, group and community. The four central components of the theory are the person, midwifery, environment and health.

\section{Metatheoretical assumptions Person}

A teenage mother who is pregnant for the first time is a whole person who embodies dimensions of body, mind and spirit. She functions in an integrated, interactive manner with her environment.

\section{Midwifery}

Midwifery is an interactive process in which a midwife as a sensitive therapeutic professional facilitates the promotion of health through the mobilization of resources.

\section{Environment}

A teenage mother who is pregnant for the first time has internal (body, mind and spirit) and external (physical, social and spiritual) environments, and she functions in an integrated, interactive manner with her environment.

\section{Health}

Health is a dynamic interactive process in the teenage mother's environment. This interaction with her environment reflects the relative health status of the mother.

\section{Methodological assumptions}

Due to the exploratory and descriptive nature of the research, the qualitative method was used. The central methodological assumption was based on functional reasoning of Botes (1995:13). This assumption entails that the research must be applicable to practice and must be useful. The major objective was to solve problems as they occur in practice in order to improve the service character of nursing.

\section{Definition of central concepts Teenage mother}

Teenage mother refers to a young woman who has reached puberty with an age ranging between $13-19$ years and who is pregnant.

\section{Experiences}

The Oxford School Dictionary (Hawking 1998:225) defines experiences as "living through" what happens to one and how one responds or reacts. In this study experiences referred to physical, psychological, emotional and cultural changes that the teenage mothers lived through during their first pregnancies.

\section{First pregnancy}

First pregnancy is referred to as the state from conception to delivery of the fetus [for the first time]. The normal duration is 280 days (40 weeks or 9 months and 7 days) counted from the first day of the last normal menstrual period (Adams, 1995:129). This definition was adopted for the purpose of the study.

\section{Research design and method}

The research study used was a qualitative, exploratory, descriptive and contextual design (Mouton, 1996:103106). A phenomenological approach was used to study the experiences of teenage mothers' first pregnancies holistically, as it was lived (Polit \& Hungler, 1997:651; Burns \& Grove, 1993:30).

\section{Population and sampling}

Fourteen (14) teenage mothers who were pregnant for the first time were purposively selected. These teenage mothers were selected during antenatal visits at a particular clinic in the Capricorn District in the Limpopo Province. The criteria for selection were: mother to be teenager, pregnant for the first time, be booked, and be 36 weeks of gestation or above. The purpose of the study was explained and informed consent obtained. The permission to conduct the study was obtained from the 
clinic management. Interviews were conducted at the teenage mother's home within two days of contact. The principles of privacy and confidentiality were adhered to.

\section{Data collection}

Data was collected through the phenomenological, unstructured in-depth interviews. One open-ended question was used; namely, "could you please tell me about your experiences of first pregnancy?" Probing as a communication skill was used (De Vos, 2001:310). Permission was obtained to use a tape recorder to record interviews and field notes were recorded (Burns \& Grove, 1993:578-581). Interviews were conducted until saturation was reached as was reflected in repeating themes (Strauss \& Corbin, 1990:188).

\section{Data analysis}

Data was analyzed by using the perceptive of Tesch's approach in Creswell (1994:155; De Vos, 2001:343). The method involved the following steps: All transcripts were read carefully to get a sense of the whole. One interesting interview was picked, read through and ideas were jotted down on the margin as they came to mind. The researcher asked the following questions: what is it about? What is the underlying meaning? The tasks were completed for all interviews. A list of all topics was made and clustered them together in similar topics. The columns as major topics, unique topics and leftovers were formed. The most descriptive wording of topics was found and was turned into categories. Grouping of the topics that relate to each other was done by drawing lines to show interrelationships. A final category was made.

Both the researcher and an independent coder analyzed transcriptions independently. Themes and categories emerged as the experiences of teenage mothers' first pregnancies. A literature control was conducted at the end of the study as a basis for comparing and contrasting findings of qualitative study (Creswell, 1994:23).

\section{Trustworthiness}

In this study trustworthiness was ensured by utilizing Guba and Lincoln's (1985:301-318) criteria.

\section{Credibility}

Credibility was established by prolonged engagement, wherein the researcher spent time with each pregnant teenager during antenatal visit to establish rapport and build a trusting relationship. The teenagers were further visited at their homes for data collection. Referential adequacy through the use of audiotape to record the findings provided a good record.

\section{Transferability}

Transferability was ensured through the establishment of a proper thick description of design methodology and accompanying literature control to maintain clarity. The purposive sampling was used to maximize ranging of specific information that could be obtained from and about the context by purposely selecting different locations and informants.

\section{Dependability}

Dependability was established through an enquiry audit where a reviewer examined the documentation of critical incidents (documents and interview notes) and products (findings, interpretations and recommendations) and attested that it is supported data.

\section{Research results and literature control}

Five (5) main themes emerged as the experiences of teenage mothers who were pregnant for the first time: inadequate information/knowledge, unplanned/ planned pregnancy, ineffective communication, under-utilization of health resources and adequate/ inadequate social support. The total number of teenage mothers who responded in the same way was indicated in brackets.

\section{Summary of research findings}

Fourteen teenage mothers were interviewed; relevant quotations from interviews and literature control were cited. Teenage mothers, who lacked information regarding physiological changes that were brought about by pregnancy were interpreted as abnormal situation totaled ten $(71 \%)$. Lee and Grubbs (1995:42), Graig and RitcherStrydom (1983:454), found that teenagers lacked factual knowledge regarding fertility and symptoms of pregnancy. Eight teenage mothers $(57 \%)$ experienced minor and unexpected disorders of pregnancy that caused both discomfort and anxiety. Ladewig et al, (1998:202) supported these findings when they stated that "common discomfort of pregnancy resulting from physiologic and anatomic changes made them to feel uncomfortable, because it was not expected would make them anxious". Three (21\%) mothers had misconceptions and were performing practices that might be harmful to the baby and themselves. No literature was found in this regard. This might be due to the lack of information regarding the childbirth process in the study participants.

Twelve $(86 \%)$ teenage mothers had unplanned pregnancies that might be attributed to under or non-utilization of Reproductive Health services ( $\mathrm{RH}$ ), especially contraceptives. Some teenagers had information about the availability and accessibility of the services but displayed ignorance. For example, statements such as contraceptives make them fat, therefore, don't like them or contraceptives make one's body jell-like were cited. Jewkes et al (2001:735) indicated that most sexually active teenagers take contraceptive breaks in order to see menses, and this time they fall pregnant. Studies that supported these findings concluded that teenagers had sex infrequently and didn't consider contraception (Ladewig et al, 1998:223). Although most teenage mothers had unplanned pregnancies, two (14\%) mothers reported that their pregnancies were planned. Niven $\&$ Walker, (1996:51) concurred and pointed out that pregnancy could still be a positive experience for a young girl. Eleven $(76 \%)$ teenage mothers had difficulty to confide in any family members about their pregnancies because of fear, not knowing that they were pregnant and denial. Some teenagers could not even realize that they were pregnant until five month, when they started to feel the fetal movements. Literature in corroboration of this reported that teenage mothers were scared, feared rejection or were in denial. Three $(21 \%)$ teenage mothers did not communicate the problems they experienced during pregnancy to anyone. Mercer (1985:62) noted that teenagers are less likely to describe physical and emotional symptoms or identify complications during pregnancy.

With regard to the utilization of the 
antenatal services, eight ( $57 \%$ ) teenagers booked antenatal clinic at 28-32 weeks of pregnancy. The reason stated as being unaware of pregnancy, afraid to go to the clinic because of negative attitude of health workers or just book so that they could deliver at a hospital. Studies conducted by Lee \& Grubbs (1995:38) showed that teenage mothers who booked late might not have been aware that they were pregnant; they also experienced fear of the unknown or lack of family support. Chandra et al (2002:121) supported these findings by pointing out that teenagers who failed to utilize the health services did not have the opportunities to have adequate nutrition, social support services and did not benefit from early diagnosis and management of pregnancy associated complications that may adversely affect the outcome for her and for the fetus.

With regard to social and emotional support, ten $(71 \%)$ teenage mothers received adequate social and emotional support from their parents. Only four (28\%) teenage mothers had minimal social and emotional support from their mothers. The teenage mothers indicated that their mothers were upset, scolding them; as result, they had guilt feelings. These findings were supported by studies conducted by Ladewig et al (1998:226) and Roles (1990:27,132) who indicated that mothers were upset, and they said things that they did not really believe in. Mothers also felt guilty and inadequate as parents. Eleven ( $76 \%$ ) teenage mothers got support from friends. Teenage mothers viewed those who were helpful or understanding of their situation as supportive. Three $(21 \%)$ teenage mothers received no support from friends who isolated them. Roles (1990:26) mentioned that when friends find out about the pregnancy they might be scared and avoid the person. Eleven (76\%) of teenage mothers received support from their partners. Only three (21\%) teenage mothers indicated that they did not receive support from their partners. Mercer (1986:57) stated that culturally men are not socialized to be actively involved with pregnancy and are not ready for such involvement.

It is clear from these findings that teenage mothers, who are pregnant for the first time, lack information regarding changes brought about by pregnancy. The findings also emphasized the importance of utilizing Reproductive Health Services and prenatal care services. Teenage mothers also experienced variable social and emotional support from parents and partners.

\section{Strengths and limitations of the study}

The main strength of this study was its preliminary data on guidelines that were aimed at supporting teenagers to cope with pregnancy and the possibilities it offered for further research.

The limitations were:

- $\quad$ There was a difficulty in getting teenage mothers to express their experiences openly, which might be due to cultural orientation especially, when discussing reproductive issues.

- The researcher was of the opinion that the word "experiences" was poorly understood; and as result clarification for operational meaning of the concept was made.

- $\quad$ Teenage mothers were seen at their homes that were vastly distributed. At times the researcher would not find them at home or would find them having visitors, despite the fact that an appointment was made.

- Interviews were conducted in SePedi and SeTswana. The tapes were translated verbatim. The original meaning of metaphors used might be lost and distorted as the transcripts were translated into English. As a result, the researcher deemed it necessary to use the direct quotes of teenage mothers' experiences.

- Data was collected from only 14 teenage mothers; findings from this study could not be generalized to all teenagers who are pregnant for the first time.

\section{Conclusion}

Teenagers present challenges to midwives as well as an opportunity to promote health. The findings have implications with regard to the designing and implementation of support programmes, future research and strengthening of Reproductive Health Care Services. The findings further suggest that the approach health care professionals used to support teenagers who are pregnant would be ineffective unless the intervention was designed from a holistic perspective in addressing the needs identified and the youth and the family in health care were involved.

\section{Bibliography}

ANON, 1996: Adolescent pregnancy. Journal American Medical Association. July 24/31, 276(4).

BARCLAY, LB; EVERITT, L; ROGAN, F; SCHMIED, V \& WYLLIE, A 1997:

Becoming a mother- an analysis of women experiences of early motherhood. Journal of Advanced Nursing. 25: 719-728.

BOTES, AC 1995: A Research model for nursing. Auckland Park: Rand Afrikaans University.

BURNS, N \& GROVE, SK 1993: The practice of nursing research, conduct, critique and utilization. Philadelphia: W.B. Saunders.

CAROLYN, L \& STEPHEN, F 1998: Unplanned pregnancies and antenatal care. Midwifery. 4 (1). March 1988: 184188.

CHANDRA, C; SCHIAVELLO, PP; RAVI, B; WEINSTEIN, AG \& HOOK,FG 2002: Pregnancy outcomes in urban teenagers. International Journal of Gvnaecological and Obstetrics. 79: 117 122.

CRAIG, AP \& RITCHER-STRYDOM, LM 1983: Unplanned pregnancies among urban Zulu schoolgirls. South African Medical Journal. 63 (19) March 1983: 452-455.

CRESSWELL, JW 1994: Research design in qualitative and quantitative approach. London: Sage Publications.

DE VOS, AS 2001: Research at Grassroots. A Prime for the caring professions. Pretoria: J.L. Van Schaik Publisher.

FUREY, A 2004: Are support and parenting programmes of value for teenage parents? Who should provide them and what are the main goals? Public Health. 1 18: 262-267.

GORDON, CP 1996: Adolescent decision making. A broadly based theory and its application to the prevention of early pregnancy. Adolescence. 13 (123): 
$561-584$

GUBA, EG \& LINCOLN, LS 1985: Naturalistic enquiry. London: Sage Publications

JACOBSON, LD; WILKINSON, C \& PILL, R 1995: Teenage pregnancy in the United Kingdom in the 90 's, the implications for primary care. Familv practice. 12: 232-236.

JEWKES, R: VUNDULE, C; MAFORAH. F \& JORDAAN, E 2001: Relationship dynamics and teenage pregnancy in SA. Social Sciences and Medicine. 52: 733744.

LADEWIG, PW; LONDON, ML \& OLDS, SB 1998: Maternal- Newborn Nursing care. Addison Wesley: Menlo Park California.

LAUFER, AB 1990: Breastfeeding: Towards Resolution of the unsatisfying Birth experience. Journal of NurseMidwifery. 35 (1). January- February 1990: 42-44

LEE,SH \& GRUBBS, LM 1995: Teenage pregnancy-psychological aspect: Prenatal care. Clinical Nursing Research. 4(1). February 1995: 38-43.

MALEMA, RN 2000: Risk factors associated with teenage pregnancy at Ga-Dikgale village in the Northern Province of South Africa. Pretoria: University of Pretoria. (unpublished M. Sc dissertation)

MARCIA, L; PATRICIA, WLSALLY, B \& SHARON, V 1980: Obstetric Nursing. London: Addison- Wesley Publishing Company.

MARLENE, C \& MACKEY, RN 1998: Adolescents description and management of pregnancy and preterm labour. Journal of Obstetrics Gvnecology Nursing. 22 (4). July-August 1998: 410 415 .

MARSHALL, C \& ROSSMAN, GB 1995: Designing qualitative research. London: Sage Publications.

MERCER, RT 1980: Teenage Motherhood : The first year. Journal of Obstetrics and Gynecology Nursing. 9: 16-27.

MERCER, RT 1985: Relationship of the birth experiences to later mothering behaviours. Journal of Nurse-Midwifery. 30 (4) July- August 1985: 204-211.

MERCER, RT 1986: First-time Motherhood: experiences from teen to fourties. Springer Publishing Company: New York

MOUTON, J \& MARAIS, HC 1993: Basic concepts in methodology of social sciences. Pretoria: Human Sciences Research Council.

NASH, ES 1990: Teenage pregnancyneed a child bears a child. South African outlook. October- November 1990: 307311.

NIVEN, A \& WALKER A Eds. 1996: Conception, pregnancy and birth. Butterworth Heinemann: Oxford.

NOLTE, AGW Ed. 1998: A textbook for midwives. Pretoria J.L. Van Schaik.

PAREKH, A \& de la RAY, C 1997: Intragroup accounts of teenage motherhood: A community based psychological perspective. South African Journal Of Psvchology. 27 (4) December 1997: 223-231

POLIT, DF \& HUNGLER, BP 1997: Nursing Research principles and method. J.B. Lippincot Company

PRIME, GM \& WINT, EA 1997: A study of the experiences of teenage pregnancy and mothering in Trinidad, Tobago and Jamaica. September 1997. Netherlands

RAND AFRIKAANS UNIVERSITY 2000: Department of Nursing Paradigm. Johannesburg. Rand Afrikaans University.

RICE, PL \& NAKSOOK, C 1998: The experiences of pregnancy, labour and birth of Thai women in Australia. Midwifery. 14: 74-84.

ROLES, P 1990: Facing teenage pregnancy. Washington: Child welfare leage of America.

SAPIRE, KE Education for sexuality. Nursing RSA Verpleging. 3 (3) March 1988: 19-21.

SCHNEIDER, C 2002: An Australian study of women's experiences of their first pregnancy. Midwiferv. 18: 238-249.
SELLERS, PM 1993: Midwifery- A textbook and reference for Midwives in South Africa. Volumel \& 2. Johannesburg: Juta \& Company.

SEIBOLD, C 2004: Young single women's experiences of pregnancy, adjustment, decision-making and ongoing identity construction. Midwifery. 20(2): 171-180.

SPENCE, SA \& ADAMS, JP 1997: African American adolescents and use of prenatal services. Journal of Black studies. 27 (4) March 1997: 543-550.

SWEET, BR 1997: Mayes Midwifery, A Textbook for Midwives. Bailliere Tindal: Toronto.

TARKKA, M; PAUNONEN, M \& LAIPPALA, P 2000: How first-time mothers cope with child care while still in the maternity ward. International Journal of Nursing Practice. 6: 97-104.

UYS, HHM \& BASSON, AA 1991: Research methodology in Nursing Penrose book Printers (Pty) Ltd: Pretoria West.

VOETEN, H 1994: Teenage pregnancy in Namibia: problems, causes, policy recommendations. Netherlands. 1-42.

WOOLLETT, A. \& DOSANJHMATWALA, N. 1989: Pregnancy and antenatal care: Attitudes and experiences of Asian women. Child, health and development. 16: 63-78. 


\section{emes, categories, direct quotes and literature control}

\begin{tabular}{|c|c|c|c|}
\hline & Categories & Direct quotes & Literature control \\
\hline ion/ & $\begin{array}{l}\text { 3.1.1 Lack of information regarding } \\
\text { physiological changes of pregnancy } \\
\text { Fetal movements ( } 6 \text { ) } \\
\text { Breast changes ( } 3 \text { ) } \\
\text { Increased vaginal discharge (2) } \\
\text { Skin changes ( } 3 \text { ) } \\
\text { 3.1.2 Lack of information regarding } \\
\text { occurrences and coping with minor } \\
\text { disorders of pregnancy ( } 8 \text { ) } \\
\text { 3.1.3 Misconceptions and practices that } \\
\text { can be harmful to mother and fetus, related } \\
\text { to lack of knowledge ( } 3 \text { ) }\end{array}$ & $\begin{array}{l}\text { "I felt something like a snake playing inside } \\
\text { my abdomen (noga e ragaraga ka mo } \\
\text { dimpeng)." } \\
\text { "My breasts were enlarged and full. I was } \\
\text { worried and I didn't know what's } \\
\text { happening." } \\
\text { "I was always wet and my mother said I } \\
\text { have premature rupture of membranes } \\
\text { (motse o thobegile) } \\
\text { "I have observed thick lines on my } \\
\text { abdomen and my umbilicus was } \\
\text { protruding." } \\
\text { "I was always ill with dizzy spells, didn't } \\
\text { know the cause." } \\
\text { "If I'm having heartburn (gala) I induced } \\
\text { vomiting to get rid of it." } \\
\text { "If I took soil before meals I didn't feel } \\
\text { nauseous and didn't vomit." } \\
\text { at the clinic because people were saying } \\
\text { they caused pregnancy to grow faster." }\end{array}$ & $\begin{array}{l}\text { Studies conducted supported thi } \\
\text { mothers lack information as they sta } \\
\text { factual knowledge about human } \\
\text { physiology, sexuality, fertility, conce } \\
\text { pregnancy". For example, one teena } \\
\text { what it meant when one misses } \\
\text { changes in body appearance and fi } \\
\text { (Graig \& Ritcher-Strydom, 1983:454; } \\
\text { Malema, 2000:43 (unpublished), 20 } \\
\text { Parekh \& de la Rey, 1997:228; Gor } \\
\text { 1980:18; Mercer, 1985:61). } \\
\text { Ignorance, misinformation and i } \\
\text { surrounding pregnancy was stated } \\
\text { Matwala, 1989:69; Nash, 1990:308; } \\
\text { Malema (unpublished), 2000:43). Pr } \\
\text { her uncomfortable and if unexpected } \\
\text { (Ladewig et al, 1998:202). }\end{array}$ \\
\hline med pregirall & $\begin{array}{l}\text { 3.2.1 Ignorance and knowledge deficit } \\
\text { regarding the use of Reproductive Health } \\
\text { Services especially contraceptives } \\
\text { resulting in unplanned pregnancy (12) }\end{array}$ & $\begin{array}{l}\text { "My pregnancy was not planned...at this } \\
\text { age especially that I'm still at school, it } \\
\text { was a mistake." } \\
\text { "I thought of an abortion but again } \\
\text { thought what if it is the end." }\end{array}$ & $\begin{array}{l}\text { The primary reason for not using cor } \\
\text { to be lack of knowledge abou } \\
\text { Reproductive Health services, i, } \\
\text { condoms and myths surrounding fe } \\
\text { for example, "I will never fall pregna }\end{array}$ \\
\hline
\end{tabular}




\begin{tabular}{|c|c|c|c|}
\hline & Categories & Direct quotes & Literature control \\
\hline & $\begin{array}{l}\text { 3.2.2 Shock and denial (12) } \\
\text { 3.2.3 Planned pregnancy (2) }\end{array}$ & $\begin{array}{l}\text { "Contraceptives makes my body jelly-like, } \\
\text { I don't like them." } \\
\text { "I missed a period and was shocked, } \\
\text { couldn't believe I was pregnant." } \\
\text { "I didn't see myself as either bad or } \\
\text { promiscuous, so it had to be impossible } \\
\text { that I was pregnant." } \\
\text { "I was wearing bigger clothes hiding } \\
\text { pregnancy." } \\
\text { "I was very happy; I didn't believe that I } \\
\text { will fall pregnant." }\end{array}$ & $\begin{array}{l}\text { "If one had sex infrequently wor } \\
\text { pregnancy was unplanned, teenage } \\
\text { denial. This was evidence in state } \\
\text { happen to me,' also wearing clothe } \\
\text { her body. Pregnancy can still be a } \\
\text { young girl (Ladewig et al, 1998: } \\
\text { Marlene \& Mackey, 1998:413; Niven } \\
\text { 1996:282; Anon,n.d.: 8). }\end{array}$ \\
\hline ommunication & $\begin{array}{l}3.3 .1 \text { Inability to establish effective } \\
\text { communication with parents (scared to } \\
\text { report/confide) (11) }\end{array}$ & $\begin{array}{l}\text { "My parents will be disappointed because } \\
\text { I let them down." } \\
\text { "If having problems I just keep quiet." }\end{array}$ & $\begin{array}{l}\text { Communication about sexual matte } \\
\text { very limited and teenage girl's } \\
\text { information were her peers, b } \\
\text { Researchers confirmed that there } \\
\text { effective communication with the } \\
\text { stated that "when I first found out } \\
\text { scared, afraid and it was most pai } \\
\text { time because my family was go } \\
\text { Teenagers are significantly less lik } \\
\text { and emotional symptoms of pr } \\
\text { complications (Marlene \& Mackey, } \\
\text { 1998:224; Roles, 1990:23; Mercer } \\
\text { Jewkes, Vundule \& Maforah, 2001:" }\end{array}$ \\
\hline ilization of health & $\begin{array}{l}\text { 3.4.1 Late bookings for prenatal care } \\
\text { services }(8) \\
\text { 3.4.2 Consult general practitioner only, if } \\
\text { having problems ( } 3 \text { ) }\end{array}$ & $\begin{array}{l}\text { "My last menstrual period was in August } \\
\text { but I started prenatal clinic in March." } \\
\text { "I was afraid to go to the clinic, health care } \\
\text { providers tell us that we are still young to } \\
\text { sleep around." }\end{array}$ & $\begin{array}{l}\text { Teenagers tend to under utilizes or } \\
\text { services. They also present to the } \\
\text { and this may be because they did } \\
\text { pregnancy, were unaware or were }\end{array}$ \\
\hline
\end{tabular}




\begin{tabular}{|c|c|c|c|}
\hline & Categories & Direct quotes & Literature control \\
\hline & & $\begin{array}{l}\text { "If I'm having problems I consult the } \\
\text { general practitioner." } \\
\text { "I only went to the clinic to book so that I } \\
\text { could deliver at the hospital." }\end{array}$ & $\begin{array}{l}\text { someone, denial or have not establi } \\
\text { cycle (Lee \& Grubbs, 1995:38; Spen } \\
\text { Marlene \& Mackey, 1998:413; Ladew) } \\
\text { 1997:301; Carolyn \& Stephen, 1998: } \\
\text { \& Pill, 1998:233). }\end{array}$ \\
\hline adequate social & $\begin{array}{l}\text { 3.5.1 Minimal emotional support from } \\
\text { mother (4) } \\
\text { 3.5.2 Received support from mothers (10) } \\
\text { 3.5.3 No support from boyfriend ( } 3 \text { ) } \\
\text { 3.5.4 Variable support from friends ( } 3 \text { ) }\end{array}$ & $\begin{array}{l}\text { "I'm still young to be a mother." } \\
\text { "Mother said I knew that you would not } \\
\text { complete you studies." } \\
\text { "My mother was very supportive; she told } \\
\text { me that now I'm a mother I must practice } \\
\text { healthy behavior." } \\
\text { "I never saw him since I fell pregnant." } \\
\text { "My friends didn't invite me they always } \\
\text { give excuses that I'm pregnant and will } \\
\text { leave me when attending parties." }\end{array}$ & $\begin{array}{l}\text { Teenage parents are vulnerable grot } \\
\text { support during pregnancy and after } \\
\text { a pregnant teenage mother receives } \\
\text { she feels about herslf and thus her lif } \\
\text { pregnancy as a teenager I didn't hav } \\
\text { Support from boyfriend was valt } \\
\text { distressed when not forthcoming. } \\
\text { about pregnancy they may be scared } \\
\text { who would feel lonely and isolated. I } \\
\text { as supportive almost as twice as fat } \\
\text { Scheineder, 2002:246; Mercer, } 1980 \\
\text { Mercer, } 1986: 57 \text { Niven \& Walker, } 1 \\
\text { Jacobson et al, 1995:233;). }\end{array}$ \\
\hline
\end{tabular}


Table 2: Guidelines of the support programme for pregnant teenagers

The guidelines were developed as possible strategies for meeting the identified needs of teenage mothers who are pregnant for the first time.

\begin{tabular}{|c|c|}
\hline Need identified & Strategy to meet the need \\
\hline $\begin{array}{l}\text { 4.1 The need for information about reproductive health, } \\
\text { sexuality, physiological changes during pregnancy, minor } \\
\text { disorders of pregnancy and misconceptions. }\end{array}$ & $\begin{array}{l}\text { The establishment of pre-pregnancy health } \\
\text { education programs: } \\
\text { - } \quad \text { Sexual health education in the form of life } \\
\text { skills as part of school curriculum; } \\
\text { Raise awareness of available services } \\
\text { through magazines, radio, television and } \\
\text { the Internet }\end{array}$ \\
\hline $\begin{array}{l}\text { 4.2 The need for information regarding utilization and the } \\
\text { importance of Reproductive Health Services }\end{array}$ & $\begin{array}{l}\text { The establishment of effective pregnancy prevention } \\
\text { programs, which are accessible for the provision of } \\
\text { information about Reproductive Health Services: } \\
\text { - The programmes to provide information and } \\
\text { counseling on contraceptives and } \\
\text { provision of condoms (males and females); } \\
\text { Provision of information of emergency } \\
\text { contraceptives; } \\
\text { Provision of information on the Choice for } \\
\text { Termination of Pregnancy Act no } 92 \text { of } 1996 .\end{array}$ \\
\hline
\end{tabular}

4.3 The need for information as evidenced by delayed antenatal services (poor motivation or service not regarded as important)
4.4 The need for enhancement of capacity for the natural social support system

-

The development of 'adolescent-friendly prenatal practice' that are accessible to teenage mothers and to provide high quality care:

The service should be respectful of cultural and social norms and empower teenage mothers to participate in their health care;

The service should provide information on the importance of antenatal services;

Raise awareness about the availability of the 'supermarket approach services' which allows teenagers to drop in at the clinic;

$\bullet$ Encouragement of the formation of an interactive framework by all people offering support to the teenage mother, namely, her family, friends and boyfriends;

- $\quad$ Encouragement of family involvement in the health care of the teenagers;

Provision of information on resource material and support to assist parents in talking to their children; 